This item was submitted to Loughborough's Research Repository by the author.

Items in Figshare are protected by copyright, with all rights reserved, unless otherwise indicated.

\title{
Assessment of cumulative sound exposure levels for marine piling events
}

PLEASE CITE THE PUBLISHED VERSION

http://dx.doi.org/10.1007/978-1-4419-7311-5_102

PUBLISHER

(C) Springer Science+Business Media

VERSION

AM (Accepted Manuscript)

LICENCE

CC BY-NC-ND 4.0

\section{REPOSITORY RECORD}

Lepper, Paul A., Stephen P. Robinson, Michael A. Ainslie, Pete D. Theobald, and Christ A.F. de Jong. 2019. "Assessment of Cumulative Sound Exposure Levels for Marine Piling Events". figshare.

https://hdl.handle.net/2134/9514. 
This item was submitted to Loughborough's Institutional Repository (https://dspace.lboro.ac.uk/) by the author and is made available under the following Creative Commons Licence conditions.

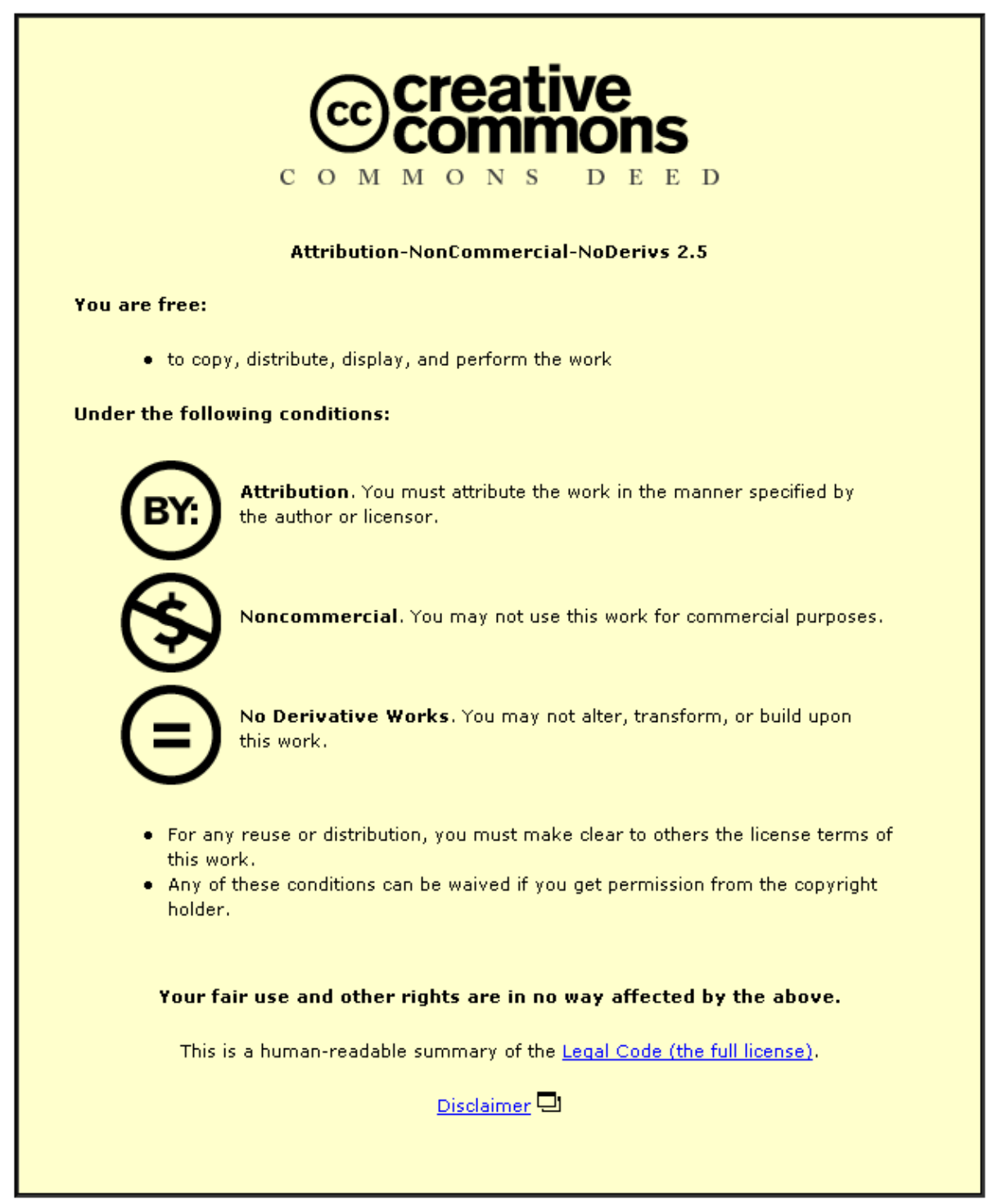

For the full text of this licence, please go to: http://creativecommons.org/licenses/by-nc-nd/2.5/ 


\title{
Assessment of Cumulative Sound Exposure Levels for Marine Piling Events
}

\author{
Paul A. Lepper ${ }^{1}$, Stephen P. Robinson ${ }^{2}$, Michael A. Ainslie ${ }^{3}$, Pete D. Theobald ${ }^{2}$, Christ A. F. de Jong ${ }^{4}$ \\ ${ }^{1}$ Loughborough University, Leicestershire LE11 3TU, UK, p.a.lepper@lboro.ac.uk \\ ${ }^{2}$ National Physical Laboratory, Teddington TW11 0LW, UK, stephen.robinson@npl.co.uk \\ ${ }^{3}$ Sonar Department, TNO, 2509 JG The Hague, The Netherlands, michael.ainslie@tno.nl \\ ${ }^{4}$ TNO Monitoring Systems, 2600 AD Delft, The Netherlands, christ.dejong@tno.nl
}

\section{Introduction}

The installation of offshore wind farms in European waters and the scale of the planned activity have led to concern over the generation of noise and its potential impact on marine life. Much of this concern is centered around the noise generated by pile driving, which is used for the installation of the turbine foundations, and its potential impact on marine life (Thomsen et al. 2006). The noise generated by pile driving has the potential to cause injury, induce temporary or permanent hearing loss, and evoke avoidance reactions. One injury criterion for marine mammals is defined as the onset of auditory permanent threshold shift (PTS) (Southall et al. 2007), which is governed by either an instantaneous peak pressure or an integrated sound exposure level. The latter is the total noise energy to which the mammal is exposed during a given duration that, for a pile-driving source, would be either the duration of the piling or the time over which the mammal is in auditory range and is known as sound exposure level (SEL). In this case, cumulative exposure can be a useful parameter. This paper considers a summation of the SELs to which the animal is exposed during the entire piling sequence.

\section{Fleeing Animal Model}

The levels at the receptor (unweighted received levels for a single hammer strike; $\mathrm{SEL}_{0}$ ) used in this paper are based on the predictions calculated from a typical piling sequence measured in UK coastal waters. This allows the calculated cumulative exposures to be compared with the thresholds obtained 
from the literature, e.g., from the criteria published by Southall et al. (2007). To do this, a trajectory is chosen for each animal whereby the animal swims away (fleeing) from the source in a straight line at constant speed, heading, and depth. To calculate the cumulative SEL ( $\mathrm{SEL}_{\mathrm{cum}}$ ), the energy received level is calculated for each individual hammer strike (Madsen 2005) and the animal's potential position at that time is then summed over the entire piling sequence.

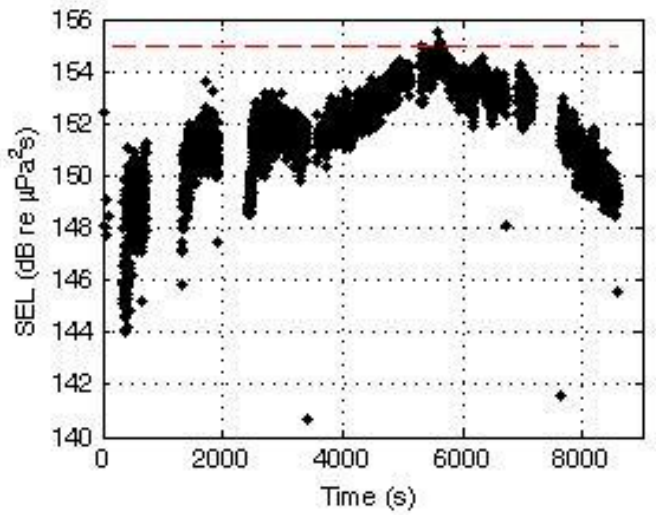

Fig. 1. Single-strike unweighted sound Fig. 2. Two-dimensional model of received $\mathrm{SEL}_{0}$ at a exposure level $\left(\mathrm{SEL}_{0}\right)$ received level for a given depth surrounding a monopile source in a rangepiling sequence at a fixed location for a dependent bathymetry.

marine monopile in shallow water. Dashed line: maximum received level of $155 \mathrm{~dB}$ re 1 $\mu \mathrm{Pa}^{2}-\mathrm{s}$.

Figure 1 shows a recorded $\mathrm{SEL}_{0}$ received level at a single location for a complete piling sequence of 4,362 hammers strikes for a monopile in about $15 \mathrm{~m}$ of water. In this case, the total piling sequence took around $2 \mathrm{~h} 20$ min with an $\sim 8-\mathrm{dB}$ increase in received level from the start to the maximum observed $\mathrm{SEL}_{0}$ received level of $\sim 155 \mathrm{~dB}$ re $1 \mu \mathrm{Pa}^{2}$-s about two-thirds of the way through the sequence. Using range-dependent modeling and taking into account bottom bathymetry, the transmission loss on a bearing from the source at various ranges can then be estimated. Figure 2 shows an estimate of received level at a 
specific depth for a given source level as a two-dimensional profile around a source. Using this approach and the source variation data taken from Figure 1, the likely received level at the animal can be estimated for each hammer strike at any range and bearing from the pile location.

\section{Cumulative Exposure Calculated for Marine Piling}

Using the methodology described in Section 2, the fleeing mammal model has been used to calculate the cumulative exposure assuming a number of conditions. Figure 3 shows an example estimate of the unweighted $\mathrm{SEL}_{\text {cum }}$ for a maximum energy source level of $210 \mathrm{~dB}$ re $1 \mu \mathrm{Pa}^{2} \cdot \mathrm{s} \cdot \mathrm{m}^{2}$ (Ainslie, de Jong, Robinson, and Lepper, this volume) for the sequence given in Figure 1, a specific start distance from the source in this example of $100 \mathrm{~m}$ and an animal swim speed of $1.5 \mathrm{~m} \mathrm{~s}^{-1}$.

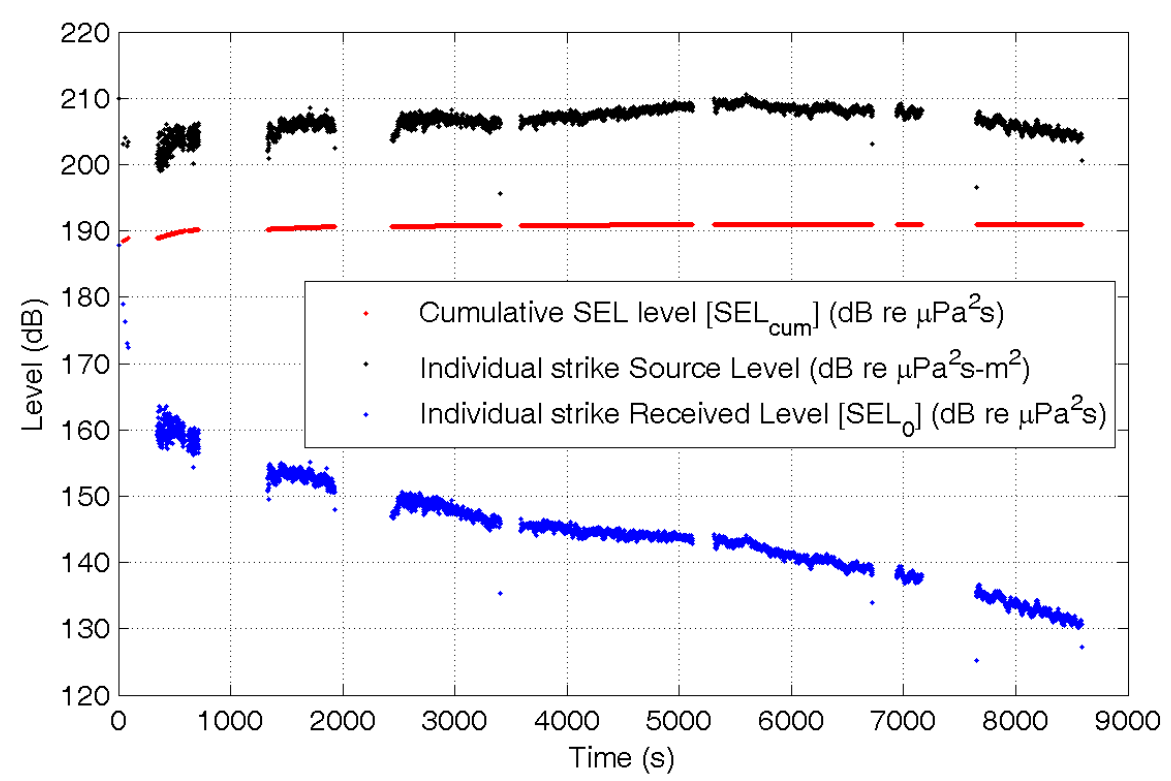

Fig. 3. Individual strike source level, unweighted received level $\mathrm{SEL}_{0}$, and cumulative exposure at receptor $\mathrm{SEL}_{\text {cum }}$ for a given piling sequence. Receptor was assumed to start $100 \mathrm{~m}$ from the source and swim away at a constant speed of $1.5 \mathrm{~m} \mathrm{~s}^{-1}$.

Using the sequence time and amplitude data, the variation in source level for each hammer strike was calculated as representing the changes in source levels seen over time (soft start) or gaps (slow start) 
in specific piling sequences (shown as the upper trace -black dots, figure 3). The individual $\mathrm{SEL}_{0}$ received level (lower trace - blue dots, Fig. 3) at the animal is then estimated for an animal swimming away from the source. The total exposure for each successive strike (middle trace, red dots, Fig. 3) was then added to give the total cumulative exposure for the entire piling sequence. This figure can then be compared with the known impact criteria threshold for cumulative exposure.

\section{Impact Zone Prediction}

The range from a source at which an animal starts, remains, or transects through and the area allowing an exposure in excess of predefined impact criteria often form the basis of impact assessments. In the case of a fleeing animal, the total cumulative exposure can be estimated for a given piling sequence on a known transect and start position. These models are then used to find a start range outside which the total exposure is kept below a predefined threshold. Figure 4 shows the effect of start range on totalSEL cum $_{\text {ch }}$ (weighted and unweighted) for the piling sequence example shown in Figure 1, with a maximum example source level of $210 \mathrm{~dB}$ re $1 \mu \mathrm{Pa}^{2} \cdot \mathrm{s} \cdot \mathrm{m}^{2}$ and a swim speed of $1.5 \mathrm{~ms}^{-1}$ applied to frequency-weighted functional hearing groups for marine mammals in both static and fleeing animal models as outlined by Southall et al. (2007). In this case, the difference in the static and fleeing animal models shows a marked increase in minimum start range to avoid exposure.

\section{Conclusions}

Both the fleeing and static model methods have been used to calculate the cumulative exposure/SEL $\mathrm{sum}_{\text {}}$ for a typical piling event during the installation of a wind turbine monopile in shallow water. The actual sequence timing, number of hammer strikes, and variation in source level and shallow-water propagation loss properties are considered. Example total exposures for functional hearing groups proposed by Southall et al. (2007) are given for each functional hearing group. This approach has also been applied to model variation in total source level (use of barrier methods) and effectiveness of soft start as an aid to development of mitigation strategies of various marine operations. 


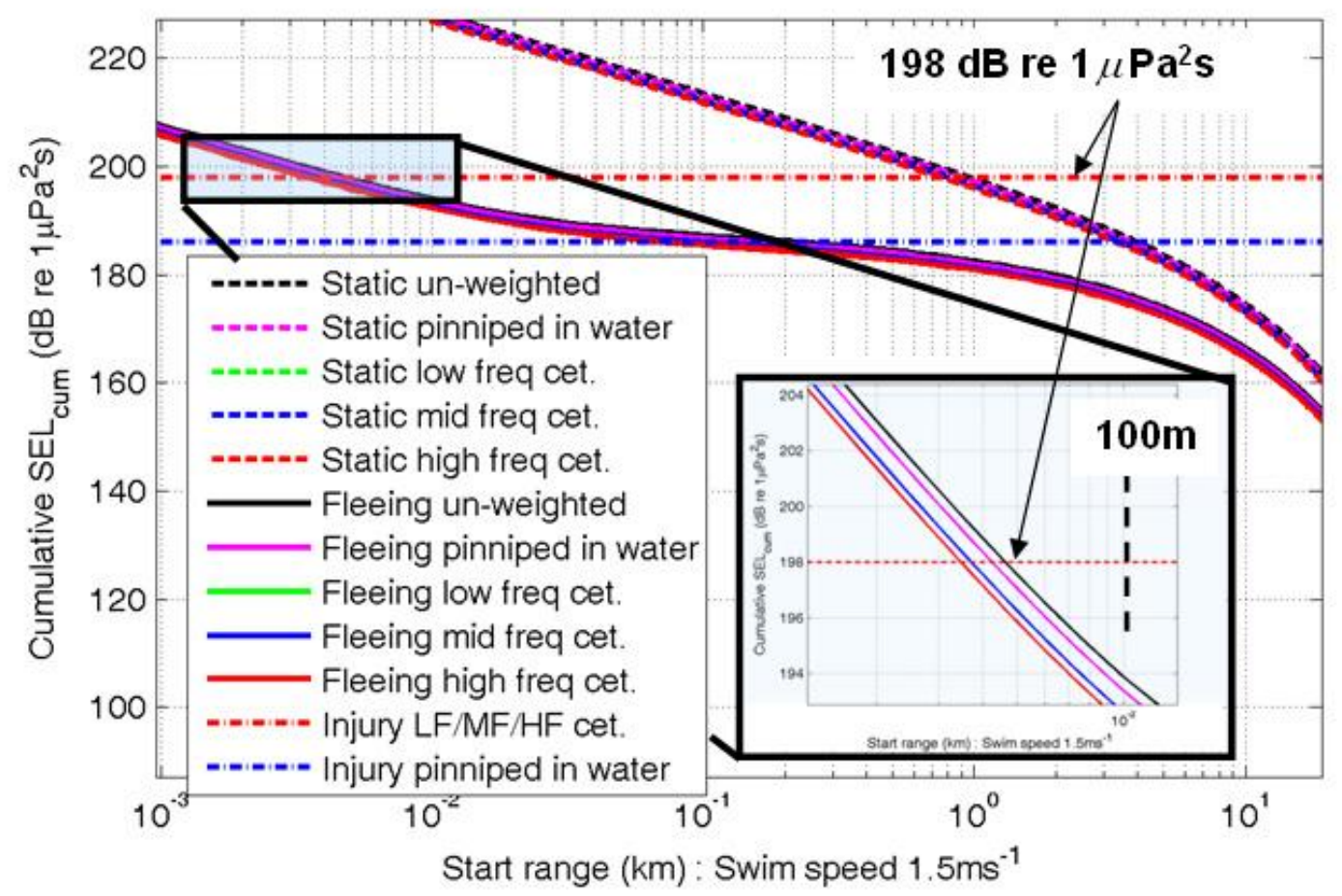

Fig. 4. Total $\mathrm{SEL}_{\text {cum }}$ versus start range for a typical piling sequence applied to different marine mammal functional hearing groups for both static and fleeing animal scenarios.

\section{References}

Madsen PT (2005) Marine mammals and noise: Problems with root mean square sound pressure for transients. J Acoust Soc Am 117:3952-3957.

Southall BL, Bowles AE, Ellison WT, Finneran JJ, Gentry RL, Greene Jr. CR, Kastak D, Ketten DR, Miller JH, Nachtigall PE, Richardson WJ, Thomas JA, Tyack PL (2007) Marine mammal noise exposure criteria: Initial scientific recommendations. Aquat Mamm 33: 411-522.

Thomsen F, Ludemann K, Kafemann R, Piper W (2006) Effects of offshore wind farm noise on marine mammals and fish. biola, Hamburg, Germany, on behalf of COWRIE Ltd. 
Figure Legends

Fig. 1. Single strike, unweighted sound exposure level $\left(\mathrm{SEL}_{0}\right)$ received level piling sequence at a fixed location for a marine monopile in shallow water. Dashed line: maximum received level of $155 \mathrm{~dB}$ re 1 $\mu \mathrm{Pa}^{2}-\mathrm{s}$.

Fig. 2. Two-dimensional model of received level $\mathrm{SEL}_{0}$ at a given depth surrounding a monopile source in a range-dependent bathymetry.

Fig, 3. Individual strike source level, unweighted received level $\mathrm{SEL}_{0}$, and cumulative exposure at receptor $\mathrm{SEL}_{\text {cum }}$ for a given piling sequence. Receptor was assumed to start $100 \mathrm{~m}$ from the source and swim away at a constant speed of $1.5 \mathrm{~m} \mathrm{~s}^{-1}$.

Fig. 4. Total $\mathrm{SEL}_{\text {cum }}$ versus start range for a typical piling sequence applied to different marine mammal functional hearing groups for both static and fleeing animal scenarios. 